\title{
SPHINX CHIONANTHI.
}

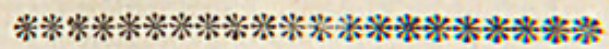

CHARACTER GENERICUS.

Antenne medio crassiores, seu utraque extremitate attenuatæ, subprismaticæ.

Ala deflexæ, (volatu graviore vespertino seu matutino).

CHARACTER SPECIFICUS, Eं.

Sphinx grisea fusco varia, alis anticis puncto centrali albo, corpore utrinque maculis tribus fulvis nigro cinctis.

Sphinx Chionanthi. S. alis integerrimis margine postico albo punctatis; primoribus strigis duabus undulatis punctoque albis, abdomine ocellis trium parium fulvis.

Smith. Abbot. ins. Amer. t. 34.

Sphinx rustica.

Fabr. ent. emend. 4. p. 366.

Varias regiones Americanas incolit insectum in tabula depictum. Larva ejus folia Chionanthi Virginicæe folia præcipue depascitur. 


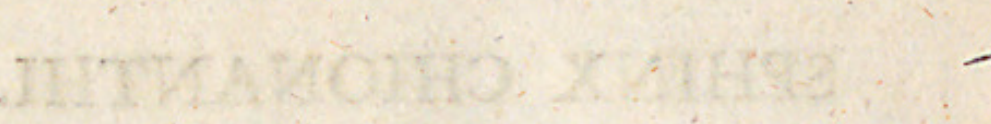



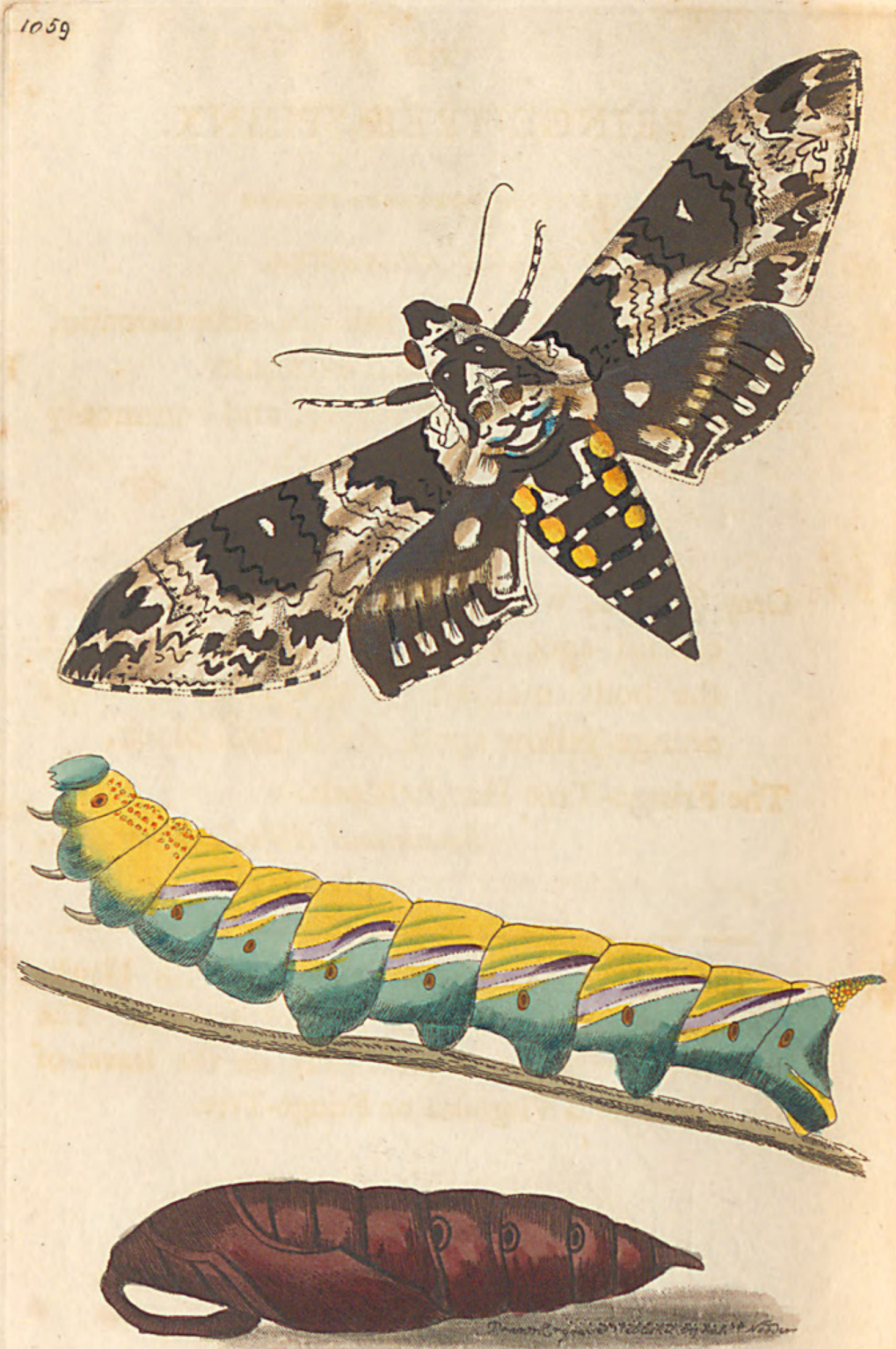


\section{THE \\ FRINGE-TREE SPHINX.}

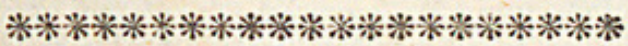

GENERIC CHARACTER.

Anteme thickest in the middle, subprismatic, and attenuated at each extremity. Wings deflected. (Flight strong, and commonly in the evening or morning).

SPECIFIC CHARACTER, छं.

Grey Sphinx, with dusky variegations, a white central spot on the upper wings, and the body marked on each side by three orange-yellow spots edged with black.

The Fringe-Tree Hawk-Moth.

Smith and Abbot's Amer. Ins. pl. 34 .

The Sphinx Chionanthi or Fringe-Tree HawkMoth, is a native of several parts of America. The larva is observed to feed principally on the leaves of the Chionanthus Virginica or Fringe-Tree. 


\section{$2 \mathrm{BHL}$ Biodiversity Heritage Library}

Shaw, George. 1813. "Sphinx chionanthi, The Fringe-tree Sphinx [PI. 1059]." The Naturalist's Miscellany 24(CCLXXXVI), -. https://doi.org/10.5962/p.322338.

View This Item Online: https://www.biodiversitylibrary.org/item/296719

DOI: https://doi.org/10.5962/p.322338

Permalink: https://www.biodiversitylibrary.org/partpdf/322338

\section{Holding Institution}

Museums Victoria

\section{Sponsored by}

Atlas of Living Australia

\section{Copyright \& Reuse}

Copyright Status: Public domain. The BHL considers that this work is no longer under copyright protection.

This document was created from content at the Biodiversity Heritage Library, the world's largest open access digital library for biodiversity literature and archives. Visit BHL at https://www.biodiversitylibrary.org. 